Arctoa (2003) 12: 91-96

\title{
THE STATUS AND TREATMENT OF THE GENUS HATTORIELLA (H. INOUE) H. INOUE
}

\author{
СТАТУС И ТРАКТОВКА РОДА HАTTORIELLA (H. INOUE) H. INOUE \\ V. A. BAKALIN ${ }^{1}$ \\ В. А. БАКАЛИН ${ }^{1}$
}

Abstract

\begin{abstract}
The morphology and taxonomic status of the genus Hattoriella (H. Inoue) H. Inoue is discussed. It is concluded that Hattoriella is a well defined taxon which merits generic status. Two new combinations - Hattoriella morrisoncola (Horikawa) Bakalin comb. nov. and $H$. subcrispa (Herzog) Bakalin comb. nov. are presented. Hattoriella includes two species: H. morrisoncola and H. subcrispa. It is shown that "Lophozia subcrispa" Herzog should be placed in the genus Hattoriella rather than in Lophozia (Dumort.) Dumort. s. str. The distribution of $H$. morrisoncola appears to be temperate East Asiatic with a more or less noticeable pacific tendency. To date this species has been found in Japan, Taiwan, Southwest China, Bhutan and Russia (Baikal Area). Hattoriella subcrispa is known from Sumatra only. Leiocolea (Hattoriella) kateninii Schljakov is synonymized with Leiocolea badensis (Gottsche) Jörg.
\end{abstract}

Резюме

Обсуждается морфология и такономический статус рода Hattoriella (H. Inoue) H. Inoue. Делается заключение, что Hattoriella является хорошо отграниченным таксоном заслуживающим ранга рода. Предлагается две новых комбинации Hattoriella morrisoncola (Horikawa) Bakalin comb. nov. и H. subcrispa (Herzog) Bakalin comb. nov. Показано, что род Hattoriella включает два вида: H. morrisoncola и H. subcrispa, а также, что "Lophozia subcrispa" Herzog должна включатся в род Hattoriella, а не в Lophozia (Dumort.) Dumort. s. str., куда она помещалась ранее. Показано, что H. morrisoncola, по-видимому, имеет неморальное восточно-азиатское распространение и в настоящее время известна из Японии, Тайваня, юго-западного Китая, Бутана и России (район оз. Байкал). Hattoriella subcrispa известна только из типового нахождения - о. Суматра. Leiocolea (Hattoriella) kateninii Schljakov должна рассматриваться в качестве синонима Leiocolea badensis (Gottsche) Jцrg.

\section{INTRODUCTION}

Plants collected by the author, in 1999, near Lake Baikal (South Siberia, Russia) were placed in the genus Hattoriella ( $\mathrm{H}$. Inoue) $\mathrm{H}$. Inoue, family Lophoziaceae due to their characteristic leaf shape and coloration, as well as the structure of their perianth and androecium. Specimens of Leiocolea (Hattoriella) kateninii Schljakov were collected in 2000 (also by the author), in the northwestern Amur Province of Russia. The holotype of Lophozia subcrispa Herzog (Sumatra) was examined in 2001. This specimen agrees with Hattoriella by appearance and some morphological features. The status of Hattoriella and related taxa is discussed below.

\section{THE STATUS OF HATTORIELLA - A HISTORICAL PERSPECTIVE}

In $1957 \mathrm{H}$. Inoue proposed a new monotypic subgenus Hattoriella $\mathrm{H}$. Inoue in the genus Lophozia (Dumort.) Dumort. to include Lophozia diversiloba Hatt. Later, in 1960, he elevated this subgenus to a separate genus Hattoriella (H. Inoue) H. Inoue to include $H$. diversiloba (Hatt.) H. Inoue and $H$. mayebarae (Hatt.) H. Inoue (Inoue, 1960). However Kitagawa (1966) treated both taxa as species of Lophozia subg. Leiocolea Müll. Frib. He also proposed that L. mayebarae was "most closely related to $L$. turbinata (Raddi) Steph. and $L$. badensis", and not to L. diversiloba. Later, Schljakov treated Hattoriella as a separate

\footnotetext{
1 - Polar-Alpine Botanical Garden-Institute, Kirovsk-6, Murmansk Province, 184256, RUSSIA ? Полярно-альпийский ботанический сад-институт, г. Кировск-6, Мурманская область, 184256, Россия - v_bak@aprec.ru
} 


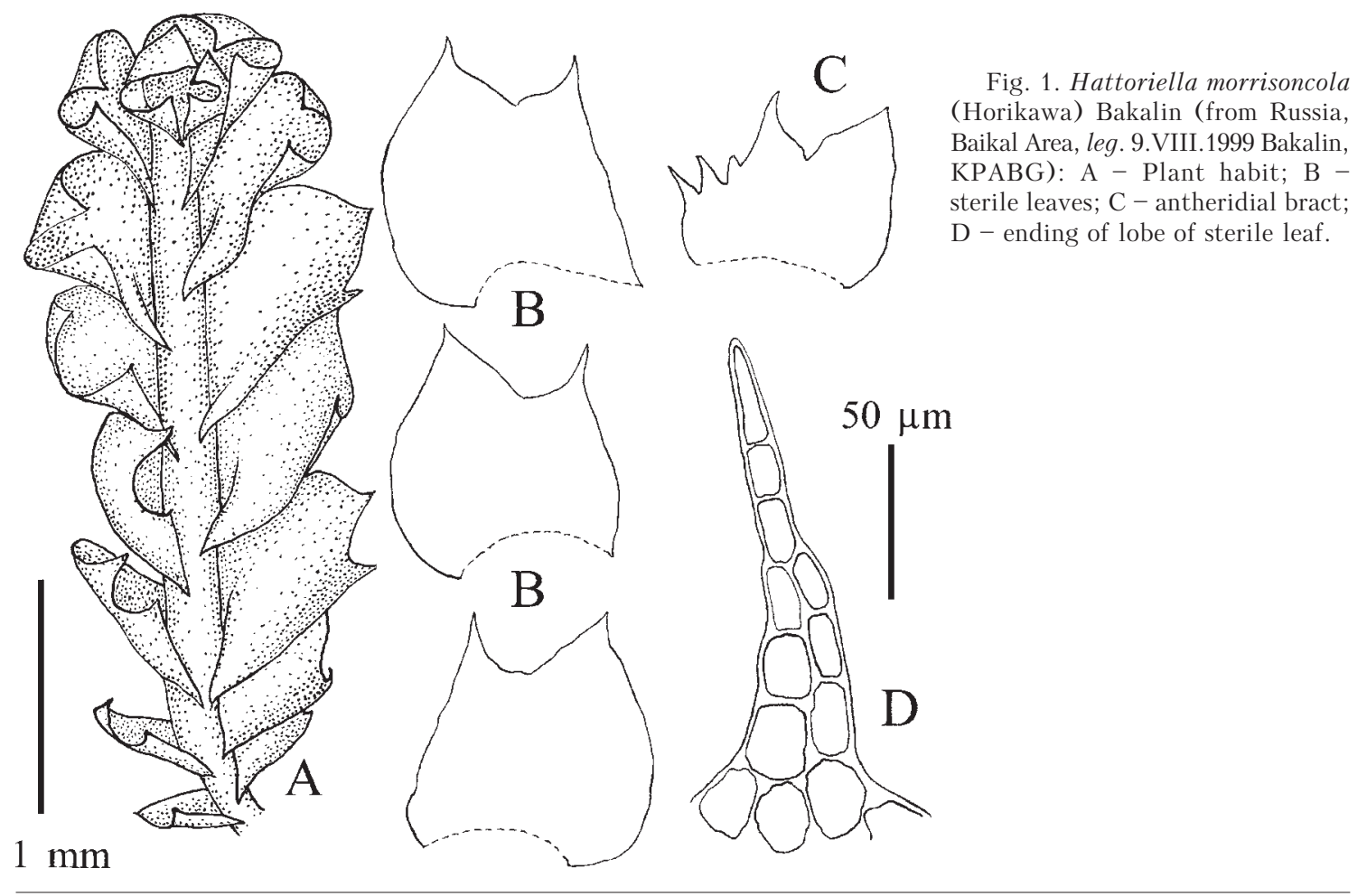

subgenus of Leiocolea (Müll.Frib.) H. Buch. In 1978 he proposed a new combination Leiocolea subg. Hattoriella (H. Inoue) Schljakov and included in this taxon Leiocolea (Hattoriella) kateninii Schljakov, described (1.c., p. 244) from Chukotka Peninsula (northeastern Russia). This position was repeated by him in 1980 . Kitagawa (1981) synonymised Lophozia diversiloba with L. morrisoncola Horikawa, with the latter as the priority name. But, Kitagawa's paper remained appatently unknown. Recently this species was reported as L. diversiloba from Bhutan (Grolle \& Long, 1990), Altai Mts (southern Siberia; Váňa \& Ignatov, 1995) and southwestern China (Jun \& Tong, 2001).

Lophozia subg. Hattoriella (and later Hattoriella as the separate genus) was established by Inoue (Inoue, 1957, 1960; Kitagawa, 1966) based on a compex of features, some of which are shared by Lophozia s. str., Orthocaulis H. Buch, and Leiocolea. Hattoriella diversiloba shows some affinity (concerning listed authors, 1. c.) to Lophozia s. str. in the following characters: dorsally secund leaves, slightly obliquely inserted leaves, more or less ascending mode of growth, absence of underleaves and weakly plicate perianth lacking a beaked mouth. Similarly Hattoriella diversiloba shows some affinity to Orthocaulis due to its 3-lobed leaves, dentate female bracts, and the presence of paraphyses, and to Leiocolea in the brownish color of plants, the few large oilbodies, the rather uniform cells of the stem tissue and the verrucose cuticle. It can be noticed that the listed features show some affinity not only to Leiocolea, Orthocaulis and Lophozia s. str., but also to Isopaches $\mathrm{H}$. Buch (uniform cells of the stem tissue, mode of growth, absence of underleaves, etc.), and Barbilophozia Loeske (brownish color of plants, the few large oil-bodies, etc.). Some of these cited traits may be found in all (or almost all) genera of Lophoziaceae (e.g. the rather uniform cells of the stem, the absence of underleaves and the verrucose cuticle), and therefore the genera of Lophozia s.l. are best separated on the base of a complex of features. The diagnostic features of Hattoriella and some related genera are given in Table 1.

K. Müller (1910) suggested that the most important feature of Leiocolea was the beaked perianth mouth, but Kitagawa (1966) showed that some Japanese species of Leiocolea (Lophozia subg. Leiocolea by Kitagawa) such as $L$. chichibuensis $H$. Inoue lack the "beak" on 
perianth mouth. Therefore the "perianth by itself is not always reliable for discriminating Leiocolea from Lophozia" (1. c., p. 101). On this basis Kitagawa suggested that Leiocolea represented only a subgenus rather than a genus. However, on the basis of other features Buch (1933), Schljakov (1980), J. Paton (1999) confirmed the generic status of Leiocolea.

Indeed, the perianth structure of some species of Hattorella closely resembles that of some species of Leiocolea (L. badensis, L. chichibuensis, L. mayebarae), but there are other striking traits differentiating Hattoriella from Leiocolea. These features are as follows: (1) 35-lobate, frequently dentate male bracts versus bilobate (with the exception of $L$. fitzgeraldiae Paton et A. R. Perry, having intermediate position); (2) presence of paraphyses (with the exception L. rutheana and L. collaris); (3) numerous tawny rhizoids in tufts under stem; (4) almost constant absence of underleaves (if present then solitary and lanceolate, versus more or less regular in most species); (5) moderately obliquely inserted leaves versus almost horizontally inserted; (6) scarcely papillose to smooth leaf cuticle versus striate-verrucose in most species. Therefore it is proposed that Hattoriella merits generic status (Fig. 1). (Note that although morphologically Leiocolea badensis appears similar to Hattoriella, the affinity is superficial. The problem of defining $L$. badensis is discussed below.)

A new combination for Lophozia morrisoncola is therefore needed.

Hattoriella morrisoncola (Horikawa) Bakalin, comb. nov. - Basionym: Lophozia morrisoncola Horikawa 1934. J. Sci. Hiroshima Univ. Ser. B. Div. 2, Bot. 2:150. Type from Taiwan: «Formosa: Mt. Morrison (Tataka-Niitakashita), prov. Tainan (Y. Horikawa, n. 11305, Aug. 1932)» (not seen).

The variable number of leaf lobes, the dioicous conditon, the presence of paraphyses and the disjunctive distribution suggest that Hattoriella is an ancient, more or less primitive member of Lophozia s.l. complex.

\section{THE DISTRIBUTION OF}

HATTORIELLA MORRISONCOLA

For fifteen years it was believed that this species was restricted to Taiwan (Lophozia morrisoncola as endemic to Taiwan) and Japan (Hattoriella diversiloba as endemic to Japan,

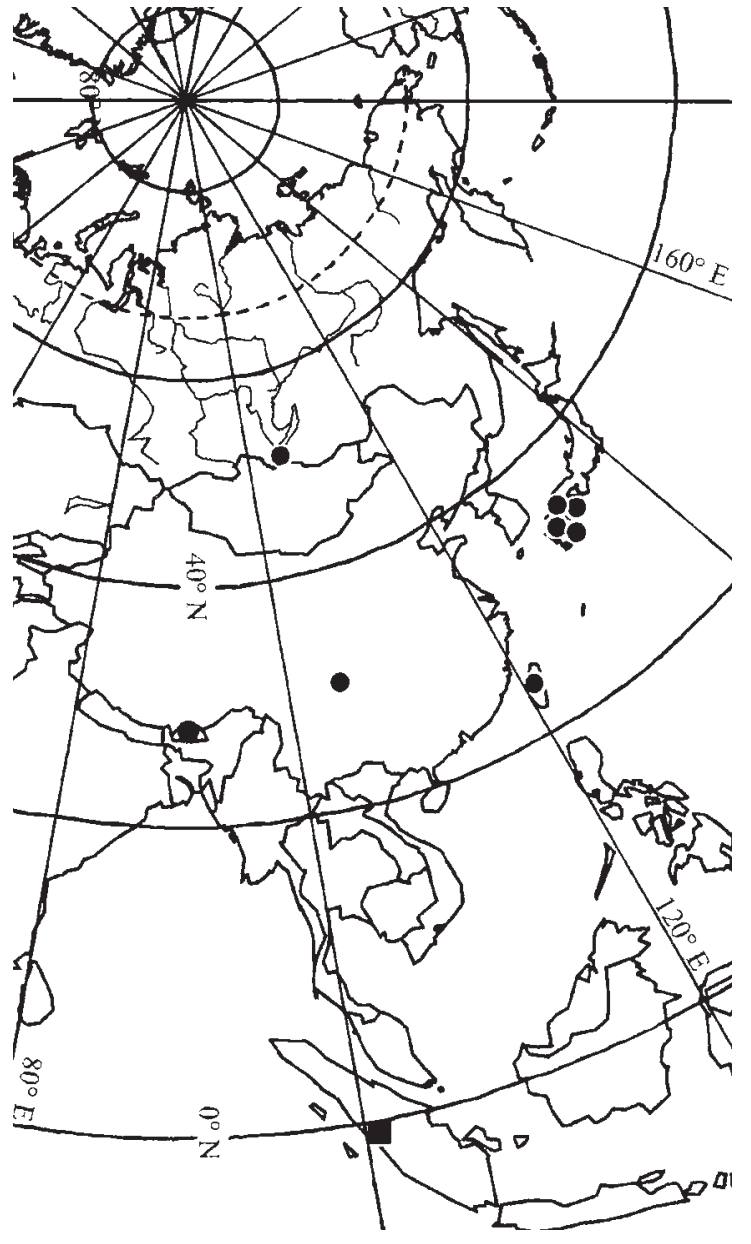

Fig. 2. The distribution for Hattoriella morrisoncola (Horikawa) Bakalin (circles) and H. subcrispa (Herzog) Bakalin (square).

see Kitagawa, 1966). However, in 1990 it was found in Bhutan (Long \& Grolle, 1990), in 1995 in Altai Mts. (Váňa \& Ignatov, 1995, as Lophozia cf. diversiloba). In 1999 this species was collected by the author from the Lake Baikal area, South Siberia (Khamar-Daban Range, Sludyanaya River, $15 \mathrm{~km}$ up stream from its mouth, limestone cliffs shaded by Abies. $600 \mathrm{~m}$ alt. leg. 9 August 1999; plants with perianths and antheridia). In 2001 it was reported for Southwest China (Jun \& Tong, 2001).

In 2001 specimens from Altai Mountains were examined by the author (N. 15/50; 15/96; "Kairu Creek, 8 km upstream 1000 m" leg. M.S. Ignatov, loaned by Prof. J. Váña) and reidentified as Leiocolea gillamnii (Austin) Evans, a species not closely related to Hattoriella morrisoncola. The plants in the specimen are monoicous 


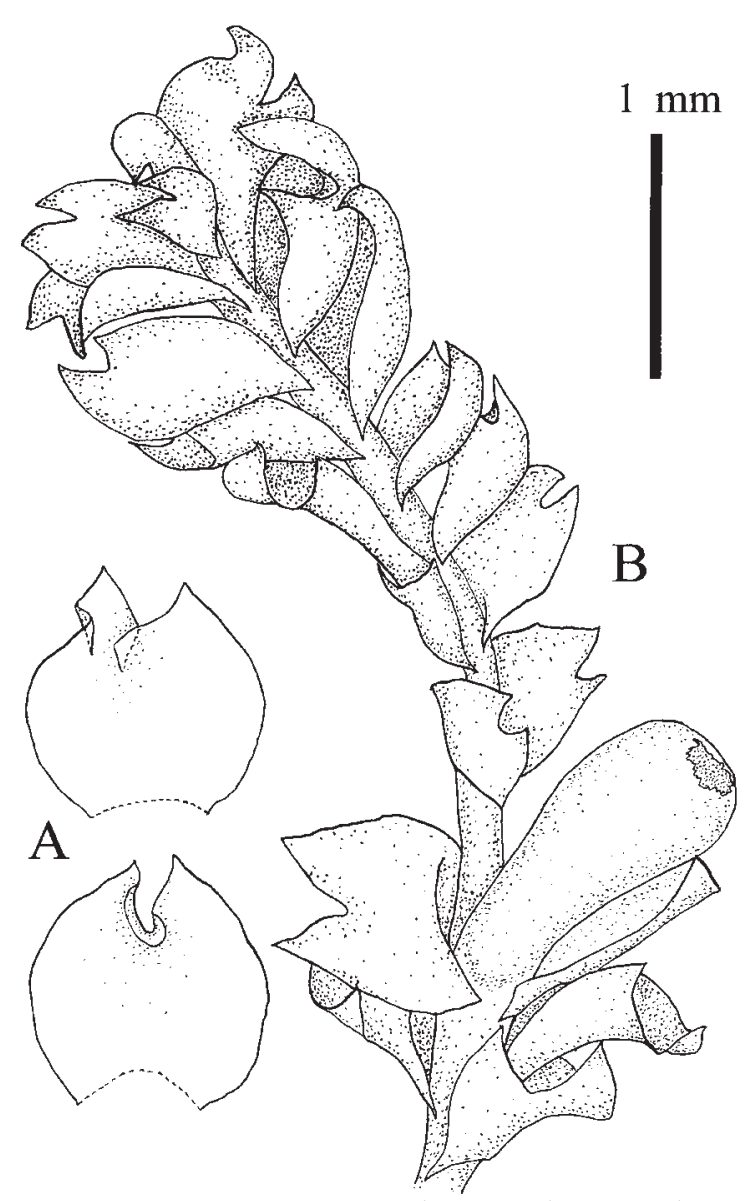

Fig. 3. Hattoriella subcrispa (Horikawa) Bakalin (from the holotype, JE): A - sterile leaves; B - plant habit.

(paroicous), with beaked perianths and obtuse, bilobate male bracts. The single feature of plants form this Altaian «Lophozia cf. diversiloba» specimen which is not characteristic for Leiocolea gillmanii is the almost constant lack of underleaves.

Currently the known distribution of Hattoriella morrisoncola includes Japan, Taiwan, Southwest China, Bhutan and Baikal Area. On the whole its distribution can be described as temperate East Asiatic with a more or less noticeable pacific tendency (Fig. 2). It may be that this species is sporadically distributed on shaded moist limestone rocks southward of South Siberia in East Asia.

\section{THE SYSTEMATIC POSITION OF LOPHOZIA SUBCRISPA HERZOG}

During the completion of the monographic study of Lophozia s. str. the type specimen of Lophozia subcrispa was examined. The holotype contains only some sterile and female plants with features similar to Hattoriella (Fig. 3): perianths lacking beaks; moderately obliquely inserted leaves; solitary lanceolate underleaves; numerous rhizoids, in tufts on ventral side of stem; and smooth to scarcely papillose leaf cuticle. It is proposed that these plants should be referred to Hattoriella rather than Lophozia s. str.

Hattoriella subcrispa (Herzog) Bakalin comb. nov. - Basionym: Lophozia subcrispa Herzog. 1943. Ann. Naturhist. Mus. Wien 53(1): 362. Holotype from Sumatra: "Padang, leg. Schild", JE!.

The species seems to be close to Hattoriella morrisoncola, but differs in the more obtuse leaf lobes and obpearate versus almost cylindrical perianths. However, the systematic position of this taxon needs further studies. The locus classicus of $H$. subcrispa is indicated Fig. 2.

\section{A RECLASSIFICATION OF LEIOCOLEA \\ (HATTORIELLA) KATENINII SCHLJAKOV}

During field trips in the summer of 2000 to Stanovoye Nagorye Uplands (Northwest of Amur Province, Russia) plants resembling a diminutive Leiocolea were collected by the author (Fig. 4, published as exsiccata by Bakalin \& Konstantinova, 2003). These plants have the following characters: (1) moderately obliquely inserted, trapezoid imbricate leaves, (2) vestigial to filiform underleaves, (3) bulging trigones in the leaf cells, (4) scarcely papillose to smooth leaf cuticle, and (5) perianth without a beaked mouth. A detailed study of the material indicates its similarity with (1) Leiocolea (Hattoriella) kateninii due to the moderately obliquely inserted leaves, and the lack of a beak on the perianth mouth, as well as with (2) Leiocolea badensis due to the scarcely papillose leaf cuticle and vestigial to filiform underleaves. It is suggested that the collected plants represent a variant intermediate between $L$. badensis and L. kateninii in their traditional treatment (cf. Müller, 1954; Schljakov, 1980).

These two taxa were separated by Schljakov, (1980) by the following characters: (1) strongly oblique to almost horizontally inserted leaves in $L$. badensis versus moderate oblique and concave to cupped imbricate leaves in $L$. kateninii, (2) absent or vestigial to filiform and lanceolate underleaves, versus filiform to lanceolate, (3) concave to moderate, rarely 


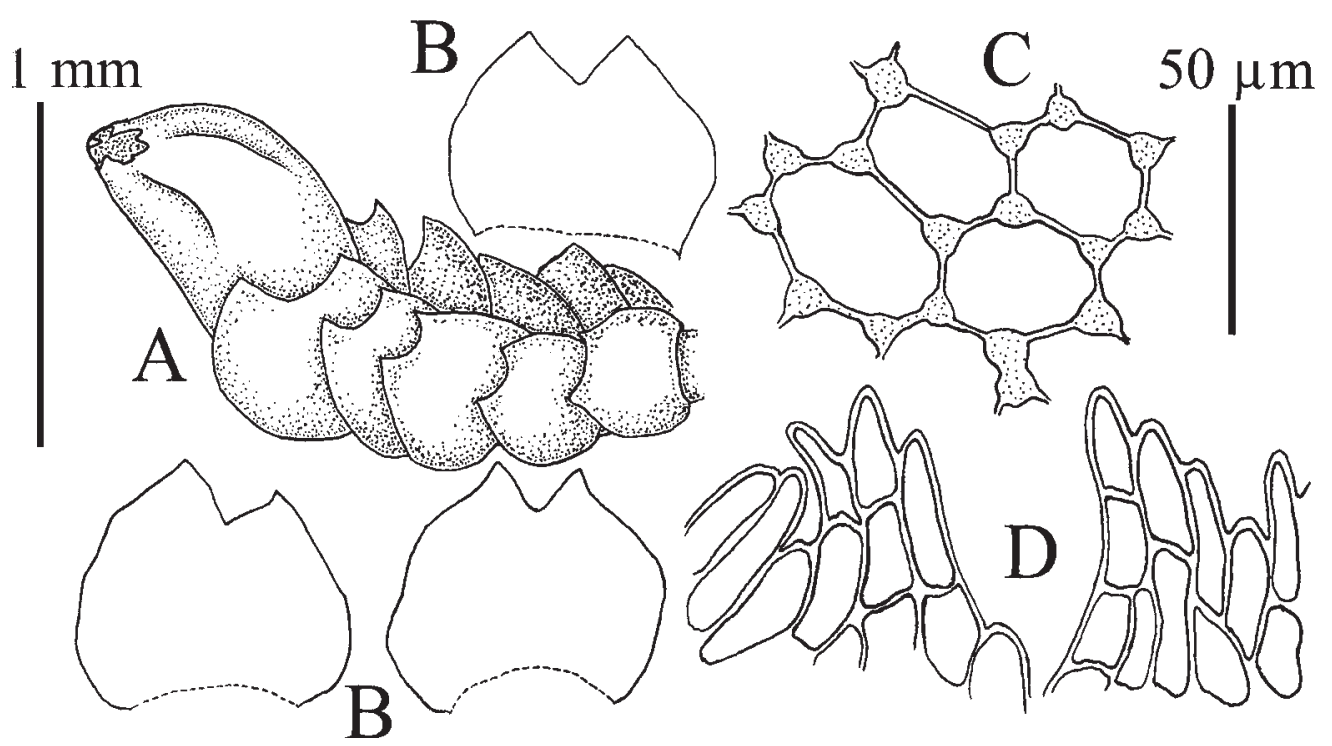

Fig. 4. Leiocolea badensis (Gott.) Jörg. (from Russia, Amur Province, Stanovoye Uplands, Udokan Range, Vil'betkan, leg. 9.VIII.2000 Bakalin, KPABG): A - plant habit; B - sterile leaves; C - cells in the leaf middle; D - mouth of the perianth.

convex trigones, versus bulging trigones, (4) smooth to scarcely papillose cuticle, versus scarcely striolate to verrucose cuticle, (5) perianth with a beaked mouth, versus unbeaked, (6) crenulate mouth of perianth, versus dentate (with 1-2 celled teeth).

With the study of type specimens of Leiocolea (Hattoriella) kateninii ("Pars orientalis peninsulae Tschukotka, sinus Laurentii”, leg. A.E. Katenin 9 July 1974, $\mathrm{KPABG}$ ), cited specimen from Amur Province and material of Leiocolea badensis from KPABG it is apparent that there is an overlap between the two taxa. Some observations confirm this opinion: 1) The angle of leaf insertion (oblique) in this species depends on the substrate moisture, with the angle of insertion varying between plants in a single specimen; 2) underleaves structure varies from almost lanceolate and regular to none; 3 ) the density of papillae on the leaf cuticle appears to depend on growth conditions; 4) the mouth of the perianth varies from crenulate to dentate (even in one population); 5) perianth varies from beaked and plicate to not beaked. Some similar observations were reported by J. Paton (1999).

Therefore the characters used to separate $L$. badensis from L. kateninii are not reliable, and it is proposed that the latter is synonymous with $L$. badensis.
Leiocolea badensis (Gottsche) Jörg., Bergens Mus. Skr. 16: 166. 1934. - Jungermannia badensis Gottsche in Gottsche et Rabenh. Hep. Eur. Exs. № 95. 1859. Germany. «bei Ueberlingen (Oberbaden)», leg. Jack. - Lophozia badensis (Gottsche) Schiffn., Lotos 51: 221. 1903. Leiocolea kateninii Schljakov, Novosti Sist. Nizsh. Rast. ("Pars orientalis peninsulae Tschukotka, sinus Laurentii”, leg. A.E. Katenin 9 July 1974 15: 244.1978 syn. nov.

Leiocolea badensis differs from species of Hattoriella in (1) absence of paraphyses, (2) almost constant presence of regular underleaves, and (3) bilobate male bracts. Some affinity is suggested by the unbeaked perianth and bistratose capsule wall, but it is proposed that these features do not indicate an evolutionary affinity but rather an accidental convergence of $L$. badensis due to growth conditions (for example, moisture).

\section{ACKNOWLEDGEMENTS}

I thank the curator of JE for the loan specimens of Lophozia s.l. and Prof. Váňa for sending for study the specimens named as Lophozia diversiloba from Altai Mts. The electronic version of distribution map of Hattoriella was kindly compiled by Mr. A.N. Savchenko. English in the manuscript was corrected by Mrs. Wynne Miles. This work was partly supported by the Russian Foundation for Basic Researches, grants 00-04-48874 and 03-04-49304. 
Table 1. The comparison Hattoriella with related genera.

Gemmae production
Paraphyses presence

Oil-bodies

scanty, grayish

\section{Leiocolea}

$-/+$

$-1+$ (rare in -

L. rutheana and

L. collaris)
Lophozia

$$
+/-
$$

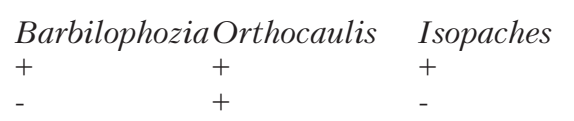

scanty to scanty, scanty, scanty, numerous, colorless to colorless to colorless colorless to grayish grayish

bluish and turquoises

Mouth of the perianth plicate, dentate beaked to plicate, plicate, crenulate plicate, to lobulate crenulate to to dentate, shortly lobulate, ciliate and crenulate to

plicate, plicate, crenulate to dentate to dentate lobulate rare ciliate lobulate

Female bracts bi-trilobate bi-tetralobate bi-tetralobate tetra-5-lobate bi-5-lobate bi-trilobate Male bracts tri-5-lobate bilobate (rare 2-4-lobate in L. fitzgeraldiae)

Number of layers

in capsule wall

Presence of small-celled

layer in the stem -

Leaf papillae $\quad+/-$

$\begin{array}{ll}2-4 & 3-5 \\ - & \\ +/- & -/+ \\ +/- & -/+ \\ \text { more or less } \quad \text { lanceolate, } \\ \text { regular, 1-3- irregular if } \\ \text { lobate, subulate } \\ \text { to lanceolate, } \\ \text { frequently terminating } \\ \text { in a slime papilla, } \\ \text { rare vestigial or absent } \\ \text { (in L. badensis) }\end{array}$

3-4 3-

$3-4$

2(3)

$\begin{array}{ll}- & - \\ +/- & +/-\end{array}$

$-$

Presence of underleaves - /+

Shape and regularity lanceolate,

of the underleaves irregular if present

Reddish or purplish pigmentation of sterile shoots -

$\begin{array}{lll}- & +/+ & -\end{array}$ $+/-\quad+/-$

distinct, distinct,

bilobed with usually bifid

often ciliate (often with 1-several lobes, basal cilia, sometimes terminated in slime reduced to two papillae or basally vestigial to connated cilia absent

\section{LITERATURE CITED}

BAKALIN, V. A., N. A. KONSTANTINOVA 2003. Hepaticae Rossica Exsiccata. Fasc. I. (N 1-25). - Kirovsk, Polygraf, 17.

BUCH, H. 1933. Vorarbeiten zu einer Lebermoosflora Fenno-Skandias. I. Ein verzuch zur Aufteilung Gattungen Lophozia Dum. und Sphenolobus Steph. - Memoranda Societatis pro Fauna et Flora Fennica 8: 282-297.

INOUE, H. 1957. Notes on the Taxonomical status of Lophozia diversiloba. - Botanical Magazine [Tokyo] 70: 357-362.

INOUE, H. 1960. A new genus Hattoriella of the Lophoziaceae. - J. Hattori Bot. Lab. 23: 37-40.

JUN, S \& C. TONG 2001. Lophozia diversiloba Hatt. (Hepaticae; Lophoziaceae) discovered in China. Arctoa 10: 43-44.

KITAGAWA, N. 1965. A revision of the family Lophoziaceae of Japan and Adjacent Regions. I. - J. Hattori Bot. Lab. 28: 239-291.

KITAGAWA, N. 1966. A revision of the family Lophoziaceae of Japan and Adjacent Regions. II. - J. Hattori Bot. Lab. 29: 101-149.

KITAGAWA, N. 1981. Miscellaneous notes on little-known species of Hepaticae, 51-70. - Hikobia Suppl. 1: 67-72.

LONG, D. L. \& R. GROLLE 1990. Hepaticae of Buthan II.
- J. Hattori Bot. Lab. 68: 381-440.

MÜLLER, K. 1910. Die Lebermoose Deutschland, Oesterreichs u. d. Schweiz. - In: Rabenhorst L, ed. Kryptogamen-Flora von Deutschland, Österreich und der Schweiz, Leipzig, Verlag von Eduard Kummer 6(1): 1-871.

MÜLLER, K. 1954. Die Lebermoose Europas (Musci Hepaticae). - In: Rabenhorst L, ed. Kryptogamen-Flora von Deutschland,Österreich und der Schweiz, Leipzig, Akademische Verlagsgesellschaft Geest \& Portig K.-G. 3(5): 641-756.

PATON, J.A. 1999. The Liverworts flora of the British Isles. - Colchester: Harley Book, 626.

[SCHLJAKOV, R. N.] ШЛЯКОВ, Р. Н. 1978. Новые виды печеночников из Сибири и Российского Далӥнего Востока. - [A new species of hepatics from Siberia and Russian Far East.] Новости сист. низи. pacm. [Novosti Sist. Nizsh. Rast] 15: 242-247.

[SCHLJAKOV, R. N.] ШЛЯКОВ, Р. Н. 1980. Печеночные мхи Севера СССР Том. 3. - [Hepatics of the North of USSR. Vol. 3.] Л., Наука [Leningrad, Nauka], 188.

VÁŇA, J. \& M. S. IGNATOV 1995. Bryophytes of Altai Mountains. V. Preliminary list of the Altaian hepatics. - Arctoa 5: 1-13. 